\title{
TOWARD STANDARDIZATION OF JOB COACHING SERVICES
}

\author{
EWA MATUSKA, ${ }^{1}$ PIOTR NIEDZIELSKI ${ }^{2}$ \\ ${ }^{1}$ Pomeranian University, POLAND \\ e-mail: ewa.matuska@apsl.edu.pl \\ 2 University of Szczecin, POLAND \\ e-mail: piotr.niedzielski@wzieu.pl
}

RECEIVED
ACCEPTED
JEL
CLASSIFICATION
KEYWORDS

ABSTRACT
3 May 2018

18 September 2018

J44, L84, 015

coaching, job coach occupation, career services

The aim of the article is to present possible path for standardization of the career coach profession via using functionalities of ESCO - European System of Competences and Occupations. The proposal is based on the literature review and its critical analysis and authors' experiences gained from international Erasmus + project "Job coach for persons with disabilities" where European standards for similar occupation were established. Authors propose to locate job coach profession among subgroup of "Personnel and careers professionals" and they have presented job description including main tasks and responsibilities of job coaches. The educational path of job coaches in terms of European Qualification frame is recommended as the next necessary step toward job coach occupation standardization.

\section{Introduction}

A job coach is an individual who helps people with career development, professional goals and long-term workplace success strategies. This role may be played occasionally by manager or supervisor at employer's settings, or it can be filled by member of human resources staff. Some career-minded professionals also hire independent job coaches on their own to help them strengthen their skills and advance in their careers. Traditionally, 
job coaching was considered kind of professional career service addressed to people with different kinds of adoption problems. Hover today, when many people several times repeat their career choices, there seems to be necessarily go ahead of old frame of supported employment system and to perceive job coaching as the service for everybody. Unfortunately, the very term coaching as well as the outline of its goals and methods till now were not able to develop sufficiently accepted theoretical background (Carey, Philippon, Cummings, 2011) and still more conceptual and practice-based research are necessary, in order to develop coaching (and job coaching as its variant) as a respected cross-disciplinary profession. Moreover, common practice of certification of job coaches by professional organizations after different kinds of short term courses and supervision of more experienced colleagues (Carroll, 2006) seems to be deeply not sufficient in terms of professional standards. This is why, authors have decided to project standardization path for job coaches as professionals who offer career support service for individuals as well as to employers searching for suitable candidates. The standardization of job coach occupation in space of Europe can be projected in a similar way like it was proposed by the international team of the Erasmus+ project who have developed European Qualification standards for job coaches for disabled persons (Röttgers, Metje, 2016).

\section{Customers of job coaching services}

Currently the context of supported employment in European space (EUSE, 2014) is used for the wide range of disfavoured groups. It includes not only different areas of disability (i.e. physical, mental health, sensory disabilities, etc.), but also other groups widely defined as being in the 'disadvantaged situation' on labour market: group of NEETs - young people not in education employment or training, offenders and ex-prisoners and people recovering from substance abuse and most recently - refugees massively entering European countries and needing effective adoption process to the rules of their labour markets.

However, going behind the frame of supported employment policy it can be stated that dominating group of potential clients for job coaches represent just all people during their career transition (Latack, 1984; Bańka, 2006), all who finish one stage of career and start with new one. Among them will be surely Millennials for whom changing jobs from time to time is a part of rational career planning, and they probably will not search for job coaching service. But, according newest research (Joia, Mangia, 2017) the important group of customers of career services may be IT specialists who are starting early exhausted with work in the IT area and more and more frequently decide for career transition to other functional areas. This trend, together with digitalization of economy will probably widening. Nevertheless, there already exist many other groups of potential customers, for example: young graduates who has realized their educational profile is not very profitable as gives them only under skilled job opportunities, women who plan to come back to labour market after break connected with care for children, people $50+$ and too early retired who want to prolongate their vocational activity. All these clients need support in their career planning, vocational profiling, finding suited jobs, and later - depends on situation - also in maintaining already posed jobs. All above suggests the demand for adequately skilled job coaches is in progress.

\section{Job coach profession formal demands}

Job coach profession till now isn't formally registered in EU although many similar professions are present in a work-space reality (Grant, Cavanagh, 2004). As non - registered occupation in Europe, job coach qualification is also (till now) not regulated in terms of the EQF- European Qualification Framework for Lifelong Learning (European Council, 2008) - the recommended rules of European Council and Commission addressed to the process 
of acquiring any qualifications. EQF demands the orientation of educational curricula on earlier defined educational outcomes which have to be described in a form of competences expected as the result of education. The new competences, planned to be acquired by the trainee: units of the new knowledge, learned new skills and trained new attitudes and behaviours - should prove (after successful finalizing the whole learning programme) that educational outcomes are filled - thus, the new qualification was really acquired by the trainee. Promoting development of job coach profession in a space of EU needs to respect the status quo, that is:

- lack of recognition of essential tasks and responsibilities, skills and competences of job coaches,

- lack of European standards for the content of education/training for job coaches,

- lack of accreditation procedures for job coach profession accepted across the Europe,

- widely offered job coaching service by different professionals without authorization.

Description of the job coach as the occupation and its probable qualification path in terms of EQF opens the gate to the standardization of this profession in space of EU. For the limited space of this paper authors will only signalize the initial stage of the standardization of job coaching services - job description of job coaching in terms of its tasks and responsibilities.

\section{Job coach occupation description}

As the potential target group for job coach services is systematically widening, thus also the concept of job coaching is during revision. The wider scope of customers means professionals who help people from different target groups in their access to open labour market are more and more needed and that they have to demonstrate profoundly differentiated specializations. The success of job coaching is when the client is able to hold satisfying job position as long he/she wants and is able to develop professionally.

Contemporary, 'job coach model' work requires complex, continuous and holistic approach to the client and his surroundings. Adopting five stages of supported employment system, job coaching process can be divided into five stages, which are: 1) client engagement; 2) client vocational profiling; 3) job finding; 4) employer engagement and optionally - depends on the situation -5) on/off job support. On each stage is demanded flexible and individual approach to every particular client. From job coaches first is expected personnel service to client in a form of "person centred planning for career development ", but this service should represent holistic personnel strategy targeted to not only to potential employee, but also to the employer.

Authors have used the frame of ESCO-European Skills, Competences, Qualifications and Occupations Internet platform (ESCO, 2013) which offers opportunity for placing any occupation in agreement with rules of European occupational classification systems. To do it successfully needs first designing job description of proposed occupation and further - describing possible qualification path for give occupation. Examining the index of occupational titles collected by ISCO - 8, the current version of the International Standard Classification of Occupations (ISCO), developed by International Labour Organization (ILO 2007, 2008) - we will not find the occupation of 'job coach'. The most fitting occupation group for the 'job coach' in ISCO-8 seems to be the occupation group number: 2423 Personnel and careers professionals. In ISCO jobs classification it is located in a following hierarchical way:

- 2 major group - professionals,

- 24 sub-major group - business and administration professionals,

- 242 minor group - administration professionals,

- 2423-unit group - personnel and careers professionals. 
Using ESCO platform with the aim to identify the possible place of 'job couch' occupation - we will see similar localization like in case of ISCO-8: personnel and careers professionals. The ESCO is still during matching its content with ISCO-8 classification but uses similar categories of occupational groups and occupations. An occupation group in ESCO clusters occupations or occupation groups with common characteristics in a hierarchical way. However, oppositely to the ISCO-8, which is only statistical tool, ESCO functionalities are much broader. ESCO is the project realizing one of the main objective of the Strategy Europe 2020 (European Commission, 2010) and its goal is to facilitate the internal EU work force mobility and work transition through easy comparing skills, competencies and qualifications obtained in different EU countries. Trying to identify on the Figure 1, the ISCO - 8 occupation group 2423 - Personnel and careers professionals in ESCO frame, we have to follow the hierarchy of occupations from "up to down", as proposes ISCO-8, until the level of unit groups (the lowest level of ISCO-8 signed as 'D'). The next lower level belongs already to ESCO - and just here can be placed 'job couch' occupation. The proposed position of the $\mathrm{JC}$ occupation is between more narrow occupations being examples of the unit level of the group 2423 - Personnel and careers professionals, but there isn't (till now) enumerated such example of occupation as 'job coach'.

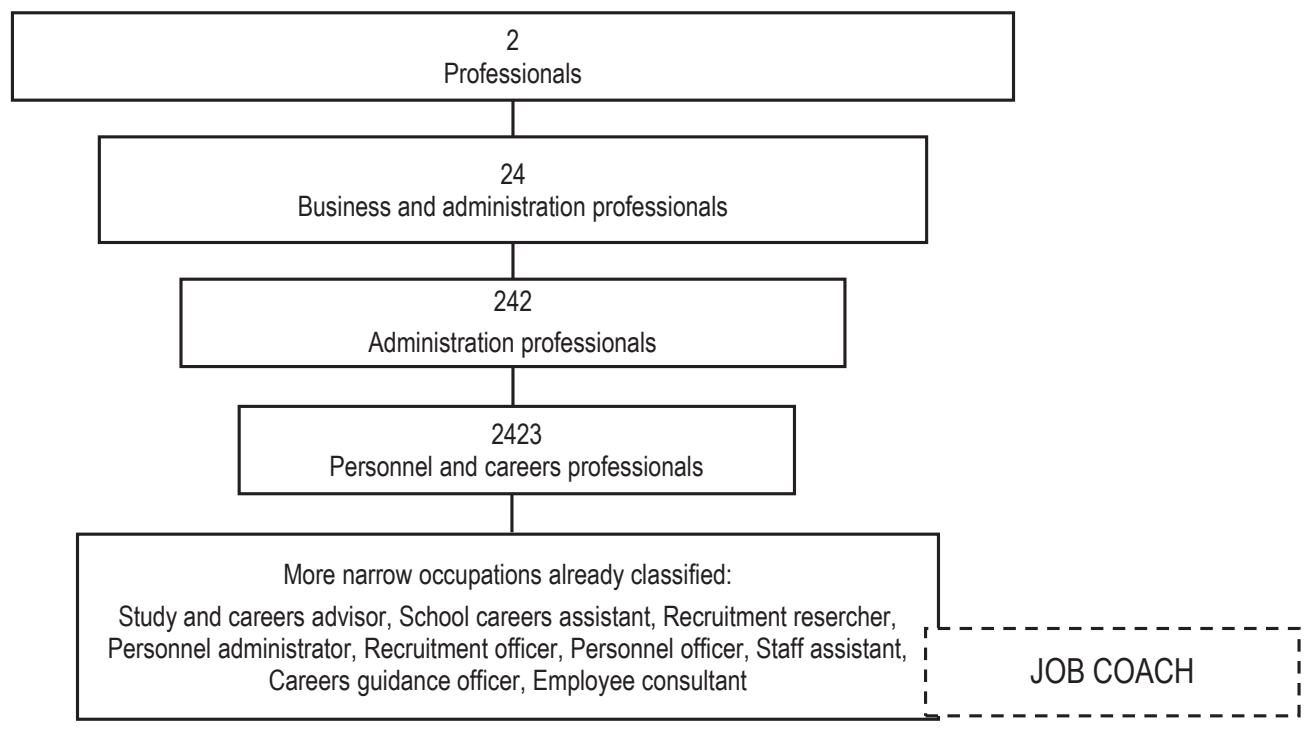

Figure 1. Proposed job coach occupation in ESCO classification

Source: authors' elaboration.

Placing the job coach occupation in a wider category of 'Personnel and careers professionals' we have to agree that job coach job description have to fulfil general demands for the work tasks and responsibilities which are referred to this category, namely its:

1. General occupational role - providing professional business services such as employee recruitment or development, occupational analyses and vocational guidance. 


\section{Main tasks of the occupations:}

a) advising on and performing personnel functions relating to employee recruitment, placement, training, promotion, compensation, and employee-management relations or other areas of personnel policy;

b) studying and analysing jobs performed in an establishment by various means, including interviews with workers, supervisors and management, and writing detailed post, job and occupation descriptions from data obtained;

c) preparing occupational information booklets or working on occupational classification systems;

d) advising and working on the foregoing and other aspects of job and occupation analyses in such fields as personnel administration, manpower research and planning, training, or occupational information and vocational guidance;

e) studying and advising individuals on employment opportunities, career choices and further education or training that may be desirable;

f) performing related tasks;

g) supervising other workers.

The general job description of the whole group of 'Personnel and careers professionals' has to be updated by much more specified job description respecting specific tasks and responsibilities of job coach who works with persons from given target group of customers.

It can be recognized two main areas of tasks of job coaches:

- career counselling - representing interests of job seekers, and

- recruitment support - representing interests of employers who need to fill vacancies by the best candidate.

The description of job coach's tasks typically undertaken by them include:

- assisting job seeker in building motivation to be employed on open labour market,

- recognizing labour market trends and organizational structures which can fit to the live situation of the client,

- identifying suitable for the client workplaces and - if necessary - helping employer(s) to adapt workplace for client's needs,

- preparing client for on-boarding to the job place agreed with employer,

- assisting client with work adaptation and with maintaining or changing job.

Above job description proves job coaches should be perceive as a wide group of professionals offering tailored services to match interest of job seekers and employers. They are more than career counsellors and more than $H R$ recruitment officers. In a wider sense - their role is to meet expectations of supply and demand on turbulently changing labour market.

\section{Conclusions}

The term 'job coaching' appears to be in use as an umbrella term for activities where a career agent guides an individual and the organization in a facilitating way to match their mutual interests - to find suitable job for jobseeker and fill job vacancy of employer with suitable candidate. This has to be win-win situation and both clients: jobseeker and employer have to be equally important for job coach. Job coach's role is to intermediate process of matching their interest on the basis of the trust given to the both sides of the contract. The occupational role of job coaches can be positioned in ESCO - European Skills, Competences, Qualifications and Occupations among occupational 
sub - group of "Personnel and careers professionals" with the number of 2423. It means - job coach represents professional job which should be acquired via sufficiently high educational level of education and further long-life learning process. Job coach's professional roles are quite complex and demand for mixture of knowledge and skills and goes far away out of traditional supported employment frames of counselling services. It acts like special kind of human resources officer offering counselling services both to individual and to organizational clients. Job coaches should be registered professionals who have passed specified qualification path proving their competence. By this way, job coach as till now not registered and popular profession can meet basic standards much clearer than supervision of professional colleagues. If educational path of job coaches would be described in equal terms of European Qualification Frames it will facilitate dissemination of job coaching services across EU member countries - like it is suitable on open European labour market. And the demand for such services will probably grow up as more and more employees are ready at least few times repeat their career choices during lifespan.

\section{Acknowledgments}

This article is a free continuation of the work initiated in the Erasmus + Project "Job coach for persons with disabilities", Project Reference: 2015-1-DE02-KA202-002430. The corresponding author of this article was the member of the project's team.

\section{References}

Bańka, A. (2006). Psychologiczne doradztwo karier; Poznań: Stowarzyszenie Psychologia i Architektura.

Carey, W., Philippon, D.J., Cummings, G.G. (2011). Coaching models for leadership development: An integrative review. Journal of Leadership Studies, 1 (5), 51-69.

Carroll, M. (2006). Key issues in coaching psychology supervision. The Coaching Psychologist, 1 (2), 4-8.

European Commission (2010). Europe 2020. A European strategy for smart, sustainable and inclusive growth. Communication from the Commission, Brussels, 3.3.2010, COM.

European Council (2008). European Qualifications Framework for lifelong learning. European Council - Official Journal C 111, 6.5. 2008.

ESCO - European Classification of Skills/Competences, Qualifications and Occupations (2013). Luxembourg: Publications Office of the European Union. Retrieved from: https://ec.europa.eu/esco/portal. DOI:10.2767/76494.

EUSE - European Union of Supported Employment (2014). European Union of Supported Employment. Toolkit for Diversity. Retrieved from: http://www.iase.ie/_wp_/wp-content/uploads/2015/05/EUSE-DIVERSITY-SE-Toolkit-2014.pdf.

Grant, A.M., Cavanagh, M. (2004). Toward a profession of coaching: Sixty-five years of progress and challenges for the future. International Journal of Evidence- Based Coaching and Mentoring, 2, 7-21.

International Labour Office (2007). Resolution Concerning Updating the International Standard Classification of Occupations. Retrieved from: http://www.ilo.org/public/english/bureau/stat/isco/docs/resol08.pdf.

International Labour Office (2008). ISCO-08, Part III, Definitions of mayor groups, sub-mayor groups, minor groups and unit groups. Retrieved from: http://www.ilo.org/public/english/bureau/stat/isco/docs/groupdefn08.pdf.

Joia, L.A., Mangia, U. (2017). Career transition antecedents in the information technology area. Information Systems Journal, 1 (27), $31-57$.

Latack, J.C. (1984). Career transitions within organizations: An exploratory study of work, nonwork, and coping strategies. Organizational Behavior and Human Performance, 3, 34, 296-322. Retrieved from: https://doi.org/10.1016/0030-5073(84)90041-2.

Röttgers, H.R., Metje, C. (2016). European quality standards for the profession job coach for persons with disabilities. Fachhochschule Münster - Grone-Schulen Niedersachsen.

Cite this article aS: Matuska, E., Niedzielski, P. (2018). Toward standardization of job coaching services. European Journal of Service Management, 3 (27/1), 151-156. DOI: 10.18276/ejsm.2018.27/1-18. 